\title{
PERENCANAAN ANGKUTAN PEMADU MODA DI BANDARA H. ASAN KABUPATEN KOTAWARINGIN TIMUR
}

\author{
Bayu Kusumo Nugroho ${ }^{1}$, Nur Misuari Wibowo ${ }^{2}$ \\ ${ }^{1}$ Manajemen Transportasi Jalan, Balai Pengelola Transportasi Darat Wilayah XI Propinsi Jawa Timur, Jl. \\ Gayungsari Barat No.11, Gayungan, Surabaya, Jawa Timur 60235, Indonesia \\ ${ }^{2}$ Balai Pengelola Transportasi Darat Wilayah XIV Provinsi Kalimantan Barat, Jl. Trans Kalimantan, Kecamatan \\ Sungai Ambawang, Kabupaten Kubu Raya, Provinsi Kalimantan Barat 78393, Indonesia \\ *prendoez@gmail.com
}

\begin{abstract}
ABSTRAK
Bandara H. Asan merupakan salah satu titik simpul transportasi yang sangat penting bagi masyarakat Kabupaten Kotawaringin Timur. Aksesibilitas perlu dipertimbangkan dengan adanya permintaan akan jasa angkutan penumpang yang berasal dari Kota Sampit menuju Bandara H. Asan untuk melakukan perjalanan dengan moda pesawat, agar dapat memberikan pelayanan yang efektif dan efisien. Tujuan dari penelitian ini adalah untuk menganalisa jumlah permintaan potensial terhadap angkutan pemadu moda, sehingga didapatkan jumlah armada yang dibutuhkan, jenis kendaraan angkutan pemadu moda, jadwal keberangkatan angkutan, serta tarif yang harus dikenakan kepada setiap penumpang angkutan pemadu moda. Dengan pengadaan jumlah armada maka perlu dilakukan analisis terhadap kelayakan investasi. Hasil analisis model logit biner nisbah dengan teknik stated preference menggambarkan perilaku pengguna jasa dalam memilih moda angkutan pemadu moda rencana diperoleh proporsi pilihan pengguna jasa terhadap moda tersebut yang telah dilakukan. Prosentase optimal orang yang mau berpindah dari kendaraan pribadi ke angkutan pemadu moda adalah sebesar $63 \%$ dan prosentase optimal pada pengguna kendaraan pribadi yang mau berpindah ke angkutan pemadu moda sebesar $39 \%$, sehingga diperoleh permintaan penumpang sebanyak 453 penumpang perhari.
\end{abstract}

Kata kunci: angkutan pemadu moda; logitbinernisbah; stted preference

\section{MODA INTEGRATED TRANSPORT PLANNING AT H. ASAN AIRPORT, EAST KOTAWARINGIN DISTRICT}

\begin{abstract}
H. Asan Airport is one of the most important transportation hubs for the people of Kotawaringin Regency Timur. Accessibility from Sampit to H. Asan Airport needs to be considered for passenger transportation services to travel by airplane mode, So that the service performance is effective and efficient. The purpose of this research is to analyze the number of potential demand for mode integration transportation, in order to obtain the required number of fleets, types of transportation modes of vehicle integration, transportation departure schedules, and tariffs that must be charged for each mode integration. passenger. By procuring the number of fleets, it is necessary to analyze the feasibility of investing. The results of the binary logit ratio analysis with stated preference techniques illustrate the behavior of service users in choosing intermodal passenger transport, the proportion of service users' choice of the mode has been done. The optimal percentage of people who want to switch from private vehicles to intermodal passenger transport is $63 \%$ and the optimal percentage for private vehicle users who want to switch to intermodal passenger transporis 39\%, so that the passenger demand is 453 passengers per day.
\end{abstract}

Keywords: binary logit; intermodal passenger transport; stated preference

\section{PENDAHULUAN}

Bandar Udara H. Asan merupakan Bandar Udara satu-satunya yang berada di Kabupaten Kotawaringin Timur. Namun untuk dapat mengakses Bandar udara H. Asan tersebut, penumpang harus menggunakan kendaraan pribadi atau taksi yang biayanya relatif mahal karena belum tersedianya angkutan pemadu moda yang bersifat massal di Bandar Udara $\mathrm{H}$. Asan. Padahal sejak diberlakukannya deregulasi di bidang angkutan udara yaitu pasca diterbitkannya Keputusan Menteri Perhubungan Nomor KM.11 Tahun 2001 tentang 
Penyelenggaraan Angkutan Udara, Keputusan Menteri Perhubungan Nomor KM.8 Tahun 2002 tentang Mekanisme Penetapan dan Perhitungan Tarif Angkutan Udara dan Keputusan Menteri Perhubungan Nomor 9 Tahun 2002 tentang Tarif Penumpang Angkutan Udara Berjadwal Dalam Negeri, Maskapai Penerbangan baru diberikan kemudahan untuk melayani angkutan udara dan beberapa diantaranya menerapkan konsep Low Cost Carrier untuk menarik dan meningkatkan jumlah penumpang. Dampak dari kebijakan tersebut menyebabkan jumlah penumpang pesawat udara khususnya untuk penerbangan domestik terus mengalami peningkatan tak terkecuali di bandar udara H. Asan. Oleh karena itu bandar udara yang merupakan suatu simpul dalam jaringan transpotasi udara dimana merupakan tempat sebagai kegiatan alih moda juga harus memperhatikan kebutuhan masyarakat akan layanan lanjutan berupa moda darat yang terintegrasi, efektif, efisien, serta mampu dijangkau seluruh masyarakat.

Berdasarkan data dari Kasubag Tata Usaha Bandar Udara H. Asan, diketahui jumlah penumpang per tahun pesawat udara di Bandar Udara H. Asan pada tahun 2013 sampai tahun 2017 mengalami peningkatan, dengan tingkat pertumbuhan rata-rata sebesar $12,74 \%$ untuk penumpang tiba dan 13,82\% untuk penumpang berangkat. Dari tingkat pertumbuhan rata-rata tahun 2013 sampai tahun 2017 tersebut diperkirakan jumlah penumpang akan mengalami peningkatan pada tahun-tahun berikutnya sehingga harus mampu dilayani oleh moda angkutan darat. Moda angkutan darat yang melayani saat ini hanya berupa taksi bandara yang berjumlah 7 unit dan angkutan sewa serta kendaraan pribadi yakni mobil dan motor. Sehingga penumpang yang tidak mempunyai kendaraan pribadi terpaksa menggunakan angkutan taksi dan angkutan sewa yang biayanya relatif mahal. Oleh karena itu diperlukan adanya kajian tentang Angkutan Pemadu Moda yang melayani rute dari Kota Sampit ke Bandara H. Asan. Tujuan dari mengetahui permintaan penumpang adalah untuk mengetahui seberapa banyak penumpang pesawat di Bandara $\mathrm{H}$. Asan mau menggunakan angkutan pemadu moda yang melayani rute dari Kawasan Perkotaan Sampit ke Bandara H. Asan atau sebaliknya sehingga dapat dirasionalisasikan untuk kebutuhan jumlah armada yang harus disediakan.

\section{METODE}

Penelitian ini dilaksanakan dengan mengambil data di Bandara H.Asan dengan melakukan survey wawancara dan melaksanakan survey sekunder. Analisis data yang dilakukan pada penelitian ini dilaksanakan yaitu menghitung Besarnya Jumlah Permintaan Penumpang (Demand). Dalam penentuan permintaan potensial, dilakukan dengan cara Analisis Logit Biner, dimana nantinya akan menghitung generalized cost perjalanan di Kabupaten Kotawaringin Timur. Setelah itu akan dibandingkan biaya antara Antara angkutan sewa dan angkutan pemadu moda rencana.

\section{Teknik Stated Preference}

Menurut Pearman (1990) bahwa teknik stated preference merupakan teknik survei yang dilakukan dengan tujuan memperkirakan keinginan atau preferensi pilihan (choice preference) dari potensi pengguna prasarana dan sarana angkutan yang merupakan respon dari masyarakat atas berbagai alternatif pilihan yang ditawarkan. Survei ini juga diperoleh informasi yang meliputi faktor-faktor yang mempengaruhi pilihan dan besarnya efek terhadap pemilihan tersebut. Gambaran umum dari teknik stated preference adalah penggunaannya pada disain eksperimental dalam membentuk serangkaian alternatif yang dihipotesis. Masing-masing individu diminta responnya jika dihadapkan pada situasi tersebut dalam keadaan yang sebenarnya (yaitu, bagaimana preferensi mereka terhadap pilihan-pilihan yang ditawarkan).

\section{Model Pemilihan Moda}

Terdapat beberapa metode dalam pemodelan pemilihan moda, salah satunya adalah logit model. Model logit biner digunakan untuk memodelkan pemilihan moda yang terdiri dari dua alternatif moda saja. Terdapat dua jenis model yang sering digunakan, yaitu model selisih dan model nisbah yang dapat diselesaikan dengan menggunakan penaksiran persamaan regresi linier. Parameter kuantitatif yang sering digunakan sebagai penentu utama dalam pemilihan moda adalah biaya perjalanan atau waktu tempuh. Pemilihan antara model logit biner selisih 
dan model logit biner nisbah dalam pemilihan moda sangat ditentukan oleh persepsi seseorang membandingkan biaya perjalanan atau waktu tempuh dalam pemilihan moda yang akan digunakan. Logit model merupakan model kombinasi sebaran perjalanan dengan pilihan moda.

Pemilihan moda sangat sulit untuk dibuat suatu model, hal ini disebabkan karena banyak faktor yang sulit dikuantifikasi, antara lain faktor kenyamanan, keamanan, keandalaan dan sebagainya. Oleh karena itu, dalam membuat model pemilihan moda pada penelitian ini, parameter yang digunakan hanya terbatas pada faktor kuantitatif, yang terdiri dari ongkos dan waktu perjalanan dengan menggunakan model logit biner nisbah. Dengan model ini, proposi $\mathrm{P}_{1}$ untuk moda 1 dinyatakan dengan persamaan berikut (Tamin, 2000) :

$$
\mathrm{P}_{1}=\frac{1}{1+\alpha\left[\frac{C 1}{c 2}\right]}
$$

Dimana:

$\mathrm{P}_{1}=$ Proporsi pemilihan moda 1

$\mathrm{C}_{1}=$ Total biaya gabungan pada moda 1

$\mathrm{C}_{2}=$ Total biaya gabungan pada moda 2

$\alpha=$ Anti logaritma dari intersep (A) pada $\mathrm{Y}_{1}=\mathrm{A}+\mathrm{B} \mathrm{X}_{1}$

\section{HASIL DAN PEMBAHASAN}

Analisis Model Logit Biner Nisbah

1. Nilai Waktu / Value of time (VOT)

Dalam penelitian ini nilai waktu yang dipakai diambil berdasarkan rata-rata pendapatan penumpang di Bandara H. Asan yaitu sebesar Rp 413.72 / menit dengan perhitungan sebagai berikut:

Tabel 1.

Nilai Waktu (value of time)

\begin{tabular}{ccccr}
\hline No & Pendapatan & $\begin{array}{c}\text { Pengguna } \\
\text { Kendaraan }\end{array}$ & $\begin{array}{c}\text { Nilai } \\
\text { Tengah }\end{array}$ & Total Pendapatan \\
\cline { 2 - 5 } & $(\mathrm{Rp})$ & (Orang) & $(\mathrm{Rp})$ & \multicolumn{1}{c}{$(\mathrm{Rp})$} \\
\hline 1 & $<\mathrm{Rp} \mathrm{1} \mathrm{Juta}$ & 1 & 500,000 & 500,000 \\
\hline 2 & Rp 1-2 Juta & 15 & $1,500,000$ & $22,500,000$ \\
\hline 3 & Rp 2-3 Juta & 41 & $2,500,000$ & $102,500,000$ \\
\hline 4 & Rp 3-5 Juta & 61 & $4,000,000$ & $244,000,000$ \\
\hline 5 & Rp 5-7 Juta & 22 & $6,000,000$ & $132,000,000$ \\
\hline 6 & $>$ 7 Juta & 15 & $7,500,000$ & $112,500,000$ \\
\hline Jumlah & 155 & & $614,000,000$ \\
\hline \multicolumn{2}{l}{ Rata-rata Pendapatan Per Bulan } & & & $3,961,290$ \\
\hline \multicolumn{2}{l}{ Nilai Waktu } & & & 413.72 \\
\hline
\end{tabular}

Rata-rata Pendapatan

Rata-rata Pendapatan

Nilai Waktu (value of time) $=\frac{\text { Total Pendapatan }}{\text { Jumlah Pengguna Kendaraan }}$

$=\frac{R p \cdot 614,000,000}{155}=R p \cdot 3,961,290 /$ Bulan

= Rata-rata Pendapatan/Standar Jam Kerja

(Henser, 1989) 
Keterangan standar jam kerja :

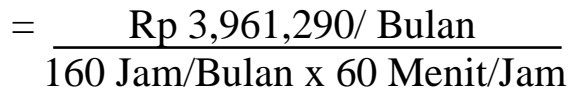

$$
\begin{aligned}
& =\operatorname{Rp} 413.72 / \text { Menit }
\end{aligned}
$$

$\begin{array}{ll}1 \text { hari } & =8 \text { jam kerja } \\ 1 \text { minggu } & =5 \text { hari kerja } \\ 1 \text { bulan } & =160 \text { jam kerja }\end{array}$

2. Analisis Pembentukan Model

Analisis model logit biner nisbah pemilihan angkutan pemadu moda dilakukan terhadap pilihan responden yang telah diperoleh melalui survey wawancara penumpang menggunakan teknik Stated Preference. Daftar pertanyaan dengan teknik Stated Preference yang digunakan dalam penelitian ini terdiri dari sejumlah pertanyaan kepada setiap responden untuk memilih menggunakan angkutan pemadu moda yang direncanakan. Pada masing-masing kondisi "pelayanan baru" dalam rencana angkutan pemadu moda yang terdapat dalam kombinasi pertanyaan Stated Preference diperoleh proporsi pengguna jasa dengan asumsi kondisi eksisting kendaraan pribadi tidak mengalami perubahan. Hasil survai yang dilakukan, dapat diperoleh beberapa data yang mengungkapkan prioritas penumpang di Kabupaten Kotawaringin Timur dalam memilih angkutan untuk bergerak dari dan ke Bandara. Untuk alasan pemilihan moda sendiri penumpang lebih memilih angkutan yang memiliki biaya perjalanan yang murah dengan persentase $47 \%$ dan angkutan yang cepat sampai ke tujuan dengan persentase 36\%. Dan waktu menunggu maksimal yang diinginkan penumpang adalah 15 menit dengan persentase $97 \%$. Jadi dari ketiga hal tersebut dibuat 8 kondisi yang nantinya dapat mempresentasikan keinginan pelajar untuk dapat berpindah ke angkutan pemadu moda.

Kondisi 1 : Tarif Angkutan Rp10.000,-, waktu di dalam kendaraan (IVT) \pm 15 menit, waktu di luar kendaraan (OVT) \pm 30 menit.

Kondisi 2 : Tarif Angkutan Rp10.000,- , waktu di dalam kendaraan (IVT) \pm 20 menit, waktu di luar kendaraan (OVT) \pm 20 menit.

Kondisi 3 : Tarif Angkutan Rp15.000,-, waktu di dalam kendaraan (IVT) \pm 15 menit, waktu di luar kendaraan (OVT) \pm 30 menit.

Kondisi 4 : Tarif Angkutan Rp15.000,-, waktu di dalam kendaraan (IVT) \pm 20 menit, waktu di luar kendaraan (OVT) \pm 20 menit.

Kondisi 5 : Tarif Angkutan Rp20.000,-, waktu di dalam kendaraan (IVT) \pm 15 menit waktu di luar kendaraan (OVT) \pm 30 menit.

Kondisi 6 : Tarif Angkutan Rp20.000,-, waktu di dalam kendaraan (IVT) \pm 20 menit, waktu di luar kendaraan (OVT) \pm 20 menit.

Kondisi 7 : Tarif Angkutan Rp25.000,-, waktu di dalam kendaraan (IVT) \pm 15 menit, waktu di luar kendaraan (OVT) \pm 25 menit.

Kondisi 8 : Tarif Angkutan Rp25.000,-, waktu di dalam kendaraan (IVT) \pm 20 menit, waktu di luar kendaraan (OVT) \pm 15 menit.

Hasil wawancara dengan menggunakan Teknik Stated Preference, pilihan tertinggi permintaan angkutan pemadu moda terhadap angkutan sewa terdapat pada kombinasi nomor 2 sebesar 9 responden sangat setuju dan 19 responden setuju dari 53 total pengguna dan pilihan terendah terdapat pada kombinasi 8 sebesar 5 responden setuju dari total pengguna. Sedangkan pilihan tertinggi permintaan angkutan pemadu moda terhadap kendaraan pribadi jugaterdapat pada kombinasi nomor 2 sebesar 6 responden sangat setuju 
dan 22 responden setuju dari 63 total pengguna dan pilihan terendah terdapat pada kombinasi 8 sebesar 5 responden setuju dari total pengguna.

\section{Total Biaya Gabungan (Generalized Cost)}

Biaya gabungan (generalized cost) merupakan biaya total yang terdiri dari waktu dan biaya perjalanan. Biaya ini dinyatakan dalam bentuk uang (Rupiah) dengan menggunakan nilai waktu untuk mengkonversikan waktu perjalanan ke dalam bentuk uang (Rupiah). Berdasarkan nilai waktu yang telah dihitung diperoleh sebesar Rp 413,72 /menit, maka dapat diperoleh total biaya gabungan angkutan pemadu moda pada kondisi eksisting kendaraan angkutan sewa dan kendaraan pribadi pada setiap kombinasi format pertanyaan stated preference dengan asumsi nilai waktu diluar kendaraan 2 kali lebih tinggi dari nilai waktu didalam kendaraan (Tamin, 2000). Biaya gabungan ini, diasumsikan bahwasanya rata - rata seorang manusia dapat berjalan dengan kecepatan $5 \mathrm{~km} / \mathrm{jam}$ (https://en.wikipedia.org/wiki/Walking) dan jarak rata - rata berjalan kaki daerah perkotaan ialah $400 \mathrm{~m}$ (SK DIRJENHUBDAT No: SK.687/AJ.206/DRJD/2002) . Jadi waktu yang dibutuhkan ialah \pm 5 menit. Diasumsikan pula untuk angkutan sewa, untuk jarak diambil jarak terjauh yaitu dari Zona 10 ke Zona 4 dengan jarak $9 \mathrm{~km}$ dengan kecepatan rata - rata 30.6 km/jam (Laporan umum Kabupaten Kotawaringin Timur,2017) dan biaya angkutan sewa diambil dari estimasi biaya perjalanan yang biasa diberikan kepada pengguna angkutan, yaitu Rp 30.000,-. Serta waktu tunggu \pm 5 menit. Diasumsikan pula untuk kendaraan pribadi, untuk jarak diambil jarak terjauh yaitu dari Zona 10 ke Zona 4 dengan jarak $9 \mathrm{~km}$ dengan kecepatan rata - rata 30.6 km/jam (Laporan umum Kabupaten Kotawaringin Timur,2017) dan biaya kendaraan pribadi diambil dari estimasi biaya perjalanan yang biasa dikeluarkan kendaraan pribadi, yaitu $R p$ 20.000,-. Serta waktu tunggu \pm 5 menit.

Contoh perhitungan :

Kondisi 1 : Tarif Rp10.000,-, waktu didalam kendaraan (IVT) menjadi 15 menit, waktu tunggu 30 menit dan waktu berjalan kaki 5 menit.

Total biaya gabungan :

$=($ IVT $x$ VOT $)+(2 \times$ WT $x$ VOT $)+(2 \times$ WJ $x$ VOT $)+$ Tarif

$=(15 \times 413,72)+(2 \times 30 \times 413,72)+(2 \times 5 \times 413,72)+$ Rp. 10.000

$=\mathrm{Rp} 45.166,-$

Perhitungan yang sama untuk mendapatkan total biaya gabungan pada masing-masing kondisi lainnya pada angkutan pemadu moda dan untuk menghitung total biaya gabungan pada angkutan sewa dan kendaraan pribadi. Sedangkan untuk menghitung nisbah total biaya gabungan disetiap kondisi adalah sebagai berikut :

Kondisi 1 : Total biaya gabungan angkutan pemadu moda adalah Rp45.166,- dan total biaya gabungan angkutan sewa adalah $\mathrm{Rp} 42.411$,-

Nisbah Total gabungan = total biaya gabungan angkutan pemadu moda $/$ total biaya gabungan angkutan sewa

$=\mathrm{Rp} 45.166,-$ / Rp 42.411,-

$=1,06$

Perhitungan yang sama untuk mendapatkan nisbah total biaya gabungan pada masingmasing kondisi lainnya. 


\section{Tabel 2.}

Total Biaya Gabungan (generalized cost) pada angkutan pemadu moda dan angkutan sewa dalam kombinasi

\begin{tabular}{rrrr}
\hline No & \multicolumn{2}{c}{ Biaya Gabungan } & Nisbah \\
\cline { 2 - 3 } & $\begin{array}{c}\text { Angkutan } \\
\text { Pemadu Moda }\end{array}$ & $\begin{array}{c}\text { Angkutan } \\
\text { Sewa }\end{array}$ & \\
\hline 1 & 45,166 & 42,412 & 1,06 \\
\hline 2 & 38,96 & 42,412 & 0,92 \\
\hline 3 & 50,166 & 42,412 & 1,18 \\
\hline 4 & 43,96 & 42,412 & 1,04 \\
\hline 5 & 55,166 & 42,412 & 1,30 \\
\hline 6 & 48,96 & 42,412 & 1,15 \\
\hline 7 & 56,029 & 42,412 & 1,32 \\
\hline 8 & 49,823 & 42,412 & 1,17 \\
\hline
\end{tabular}

Tabel 3 Total Biaya Gabungan (generalized cost) pada angkutan pemadu moda dan kendaraan pribadi dalam kombinasi

\begin{tabular}{rrrr}
\hline No & \multicolumn{2}{c}{ Biaya Gbungan } & Nisbah \\
\cline { 2 - 3 } & $\begin{array}{c}\text { Angkutan } \\
\text { Pemadu Moda }\end{array}$ & $\begin{array}{c}\text { Kendaraan } \\
\text { Pribadi }\end{array}$ & \\
\hline 1 & 45.166 & 32.412 & 1,39 \\
\hline 2 & 3.896 & 32.412 & 0,12 \\
\hline 3 & 50.166 & 32.412 & 1,55 \\
\hline 4 & 4.396 & 32.412 & 0,14 \\
\hline 5 & 55.166 & 32.412 & 1,70 \\
\hline 6 & 4.896 & 32.412 & 0,15 \\
\hline 7 & 56.029 & 32.412 & 1,73 \\
\hline 8 & 49.823 & 32.412 & 1,54
\end{tabular}

\section{Persamaan Regresi}

Persamaan regresi yang berbentuk $Y=A X B$ dapat dilinearkan dengan menggunakan pendekatan "double-log transformation" sehingga menjadi fungsi linear

$\log Y=\log A+B \log X$,

yang dapat ditulis kembali dalam bentuk persamaan linear

$Y=A+B X$.

Hal ini diperkuat dengan pernyataan Ofyar Z. Tamin (2000), dengan asumsi:

$Y=\log (1-P 1) / P 1$

$X=\log (C 1 / C 2)$

Maka persamaan tidak linear dapat ditulis kembali dalam bentuk persamaan linear: $Y=A+B X "$

Setelah persamaan nonlinear tersebut ditransformasikan ke dalam bentuk fungsi linear, maka dilakukan analisis untuk menghasilkan persamaan regresi linear dengan bantuan program Microsoft Excel 2013. Setelah diketahui nilai A dan B dari pendugaan parameter selanjutnya dapat disusun model logit biner nisbah dengan persamaan:

$$
P=\frac{1}{\left(1+\left(\alpha \times\left(W^{\beta}\right)\right)\right.}
$$


Hasil perhitungan model logit biner nisbah pemilihan moda angkutan pemadu moda telah terbentuk, maka proporsi pilihan pengguna jasa terhadap angkutan pemadu moda pada setiap kondisi nisbah total biaya gabungan angkutan pemadu moda dengan angkutan sewa dan kendaraan pribadi dapat digambarkan pada kurva diversi sebagaimana ditampilkan pada kurva $S$ dibawah ini:

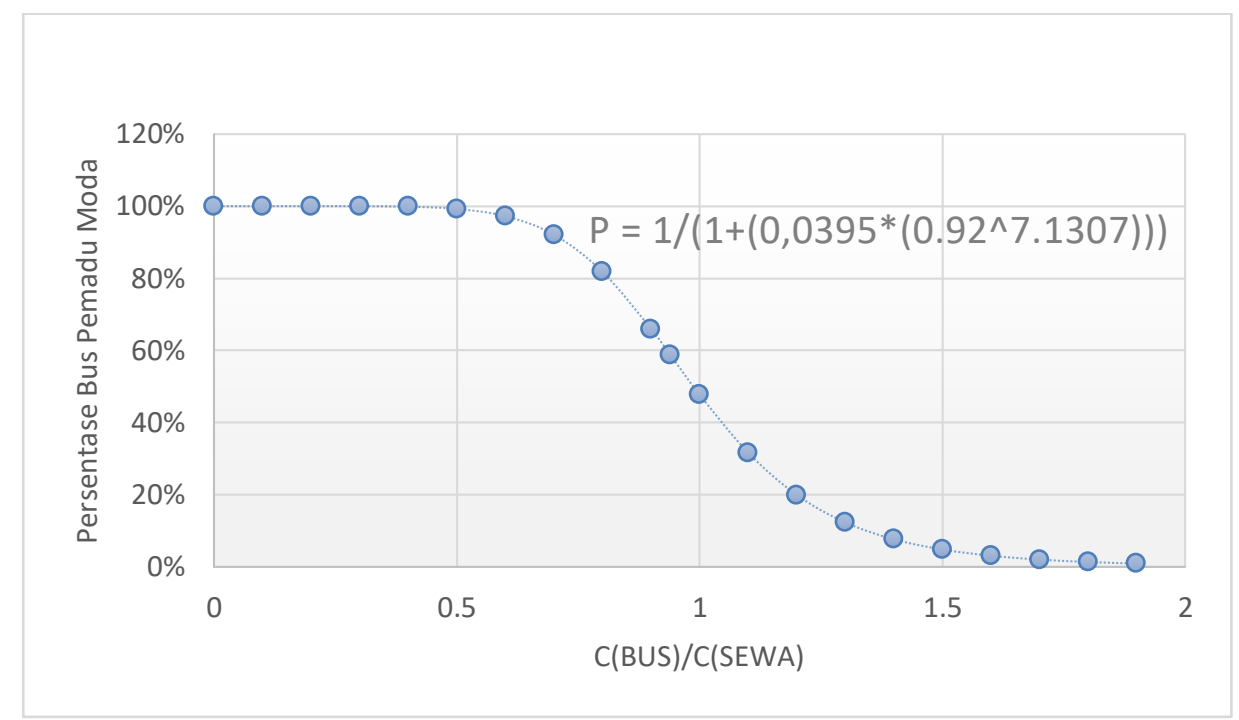

Gambar.1 Kurva S Pengguna Angkutan Pemadu Moda dari Pengguna Angkutan Sewa

Kombinasi yang paling optimal terjadi pada kondisi 2 dimana sebesar $63 \%$ orang akan berpindah ke angkutan pemadu moda

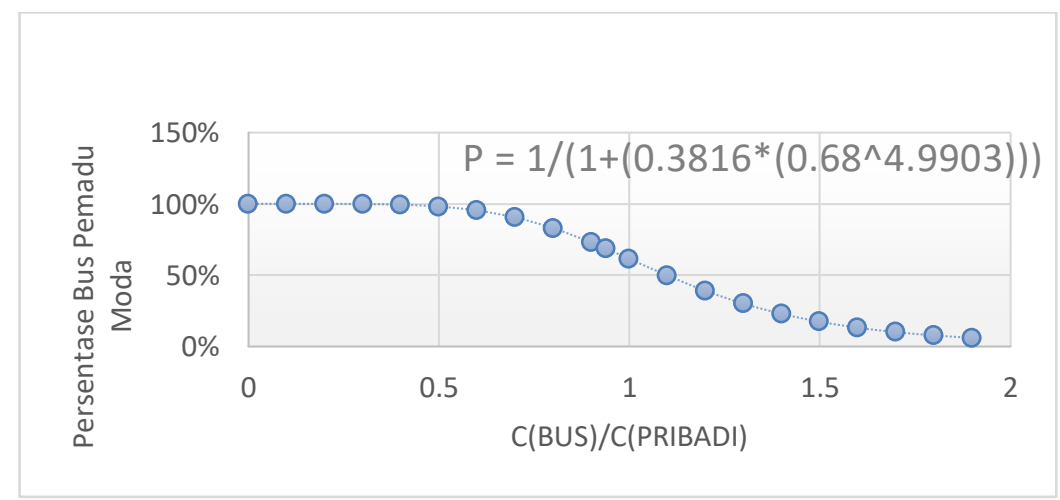

Gambar.2 Kurva S Pengguna Angkutan Pemadu Moda dari Pengguna Kendaraan Pribadi

Kombinasi yang paling optimal terjadi pada kondisi 2 dimana sebesar $39 \%$ orang akan berpindah ke angkutan pemadu moda

Dari proses analisis pembentukan model logit biner nisbah untuk menggambarkan perilaku pengguna jasa dalam memilih moda angkutan pemadu moda rencana diperoleh proporsi pilihan pengguna jasa terhadap moda tersebut. Dari model tersebut diperoleh perbedaan proporsi dari masing masing kondisi pelayanan angkutan pemadu moda rencana dengan variabel kuantitatif pelayanan angkutan pemadu moda rencana yang terdiri dari tarif dan waktu total perjalanan yang ditawarkan melalui metode survei Stated Preference. Sampel yang diambil sebesar 443 orang/hari dari Kabupaten Kotawaringin Timur menuju Bandara H. Asan dan 444 orang/hari dari Bandara H. Asan menuju Kabupaten Kotawaringin Timur yang 
didapat dari populasi penumpang dari Kabupaten Kotawaringin Timur menuju Bandara $\mathrm{H}$. Asan dan arah sebaliknya dikalikan dengan proporsi orang yang akan menggunakan angkutan pemadu moda rencana, berikut perhitungan jumlah permintaan angkutan pemadu moda rencana berdasarkan model logit biner:

Tabel.3 Jumah Permintaan Angkutan Pemadu Moda Rencana Berdasarkan Model Logit

\begin{tabular}{ccccccc}
\hline Asal - & $\begin{array}{c}\text { Populasi } \\
\text { Tujuan }\end{array}$ & $\begin{array}{c}\text { Pengguna } \\
\text { Kendaraan } \\
\text { (orang/hari } \\
\text { angkutan } \\
\text { sewa }\end{array}$ & $\begin{array}{c}\text { Mau Berpindah ke } \\
\text { Angkutan Pemadu } \\
\text { Moda Rencana dari } \\
\text { angkutan sewa } \\
\text { (orang/hari) }\end{array}$ & $\begin{array}{c}\text { Proporsi } \\
\text { kendaraan } \\
\text { pribadi }\end{array}$ & $\begin{array}{c}\text { Mau Berpindah ke } \\
\text { Angkutan Pemadu } \\
\text { Moda Rencana dari } \\
\text { kendaraan pribadi } \\
\text { (orang/hari) }\end{array}$ & $\begin{array}{c}\text { Rata- } \\
\text { rata }\end{array}$ \\
\hline $\begin{array}{c}\text { Sampit - } \\
\text { Bandara }\end{array}$ & 443 & $63 \%$ & 279 & $39 \%$ & 173 & 226 \\
\hline $\begin{array}{l}\text { Bandara } \\
\text {-Sampit }\end{array}$ & 444 & $63 \%$ & 280 & $39 \%$ & 174 & 227 \\
\hline \multicolumn{2}{c}{ Total } & 887 & 559 & & 347 & 453 \\
\hline
\end{tabular}

Jadi permintaan potensial dari Sampit ke Bandara adalah 226 penumpang dan dari Bandara ke Sampit adalah 227 penumpang, total permintaan keseluruhan adalah 453 penumpang.

\section{SIMPULAN}

Proses pemilihan moda diasumsikan bahwa setiap pengguna jasa akan memilih moda yang meminimumkan kombinasi linear antara jarak, waktu dan biaya, yang disebut dengan total biaya perjalanan. Proses analisis pembentukan model logit biner nisbah untuk menggambarkan perilaku pengguna jasa dalam memilih moda angkutan pemadu moda diperoleh proporsi pilihan pengguna jasa terhadap moda tersebut. Dari model tersebut diperoleh perubahan proporsi dari proporsi eksisting pemilihan moda angkutan pemadu moda menjadi proporsi baru berdasarkan kombinasi perubahan variabel kuantitatif pelayanan angkutan pemadu moda yang terdiri dari tarif dan waktu total perjalanan yang ditawarkan melalui metode survey Stated Preference.

\section{DAFTAR PUSTAKA}

, 1996, Keputusan Direktur Jendral Perhubungan Darat No. 274/HK.105/DRID/96. _, 2002, SK. DIRJEN HUBDAT No 687 tahun 2002.

2003, KM 35 tahun 2003 tentang Penyelenggaraan Angkutan Orang Di Jalan Dengan Kendaraan Bermotor Umum.

2009, Undang-Undang Republik Indonesia Nomor 22 Tahun 2009 tentang Lalu Lintas Angkutan Jalan

Anonim. 2008. Wikipedia. https://en.wikipedia.org/wiki/Walking. Diakses tgl 25/12/2021.

Ofyar Z. Tamin, 2000, Study Evaluasi Jumlah Kendaraan dan Tarif Angkutan Umum di DKI Jakarta, Jurusan Tekhnik Sipil ITB, Bandung.

Miro, Fidel. 2004. Perencanaan Transportasi. Erlangga, Jakarta.

Morlok, Edward. 1998. Pengantar Teknik dan Perencanaan Transportasi. Erlangga, Jakarta. 
Ortuzar, J.D. dan Willumsen, L.G. 1994. Modeling Transport, Second Edition. John Wiley and Spns Ltd.

Tim Praktek Kerja Lapangan Kabupaten Kotawaringin Timur, 2017, Pola umum transportasi darat Kabupaten Kotawaringin Timur, STTD, Bekasi.

Ilahi, R, 2011, Perencanaan Angkutan Pemadu Moda di Bandara Tjilik Riwut Kota Palangkaraya, STTD, Bekasi

Wicaksono, T, 2012, Perencanaan Angkutan Pemadu Moda Di Bandara Sultan Syarif Kasim II Kota Pekanbaru, STTD, Bekasi

Rahmadi, M, 2016, Perencanaan Angkutan Pemadu Moda Kota Solok - Bandara Internasional Minangkabau di Kota Solok, STTD, Bekasi 
Jurnal Teknologi Transportasi dan Logistik Volume 2 No 1, Juni 2021, Hal 1 - 10

p-ISSN 2716-2990

Pusat Penelitian dan Pengabdian Masyarakat Politeknik Transportasi Darat Bali

e-ISSN 2745-8954 